\title{
Practices of Human Resource Accounting Disclosure: A Comparative Study across ASEAN Countries
}

\author{
Wiyadi $^{1, *}$, Sayekti Endah Retno Meilani ${ }^{2}$, Imanda Firmantyas Putri Pertiwi ${ }^{2}$, \\ Rina Trisnawati ${ }^{1}$, Nor Hazana Abdullah ${ }^{3}$ \\ ${ }^{1}$ Faculty of Economic and Business, Universitas Muhammadiyah Surakarta, Indonesia \\ ${ }^{2}$ Faculty of Economic and Islamic Business, Institut Agama Islam Negeri (IAIN) Surakarta, Indonesia \\ ${ }^{3}$ Faculty of Technology Management and Business, Universiti Tun Hussein Onn Malaysia, Malaysia
}

Received November 22, 2020; Revised April 21, 2021; Accepted May 10, 2021

\section{Cite This Paper in the following Citation Styles}

(a): [1] Wiyadi, Sayekti Endah Retno Meilani, Imanda Firmantyas Putri Pertiwi, Rina Trisnawati, Nor Hazana Abdullah , "Practices of Human Resource Accounting Disclosure: A Comparative Study across ASEAN Countries," Universal Journal of Accounting and Finance, Vol. 9, No. 3, pp. 306 - 315, 2021. DOI: 10.13189/ujaf.2021.090304.

(b): Wiyadi, Sayekti Endah Retno Meilani, Imanda Firmantyas Putri Pertiwi, Rina Trisnawati, Nor Hazana Abdullah (2021). Practices of Human Resource Accounting Disclosure: A Comparative Study across ASEAN Countries. Universal Journal of Accounting and Finance, 9(3), 306 - 315. DOI: 10.13189/ujaf.2021.090304.

Copyright $\odot 2021$ by authors, all rights reserved. Authors agree that this article remains permanently open access under the terms of the Creative Commons Attribution License 4.0 International License

\begin{abstract}
Disclosure of human resource accounting is an important facet of sound corporate governance to ensure organizational sustainability. However, practices of human resource accounting disclosure (HRAD) have not been made mandatory among Asian countries and therefore to what extend the companies have reported their human resource accounting is not evident. This study aimed to describe HRAD practices among top ranked companies based on ASEAN Corporate Governance Scorecard which include Indonesia, Malaysia, Vietnam, Philippines, Thailand and Singapore. Assessment of HRAD practices was done based on sixteen criteria based on previous studies. A total of 195 companies were assessed based on their annual reports in year 2014 and 2015. The study found that Indonesia has the highest HRAD practices (71\%), followed by Thailand (66\%), Vietnam (65\%), Malaysia (59\%), Singapore (43\%) and Philippines (40\%). It is also found that separate HRAD is almost non-existent except a few companies in Philippines and Malaysia. This indicates that HRAD practices need to be institutionalized for better governance in Asean countries.
\end{abstract}

Keywords Human Resource Accounting Disclosure (HRAD), ASEAN Countries, HRM Practices

\section{Introduction}

Human resources are the vital assets of organization not only in terms of their contributions to organizational performance (Chand \& Katou, 2007) but also market competitiveness (Izvercianu, Radu, Miclea, \& Ivascu, 2012) and long term sustainability (Boudreau \& Ramstad, 2005). Kong \& Thomson (2009) claimed that capabilities of human resources in forms of their intelligence, expertise, skills and abilities are the driving force of high performing organization. In fact, Beattie, Smith, \& Beattie (2010) assert that human resource is a significant value creation driver in knowledge-based economy.

Recognizing its importance, attempts have been made since 1960s to quantify and recognize human costing in the balance sheet (Flamholtz \& Bullen, 2002) which is widely known as Human Resource Accounting (HRA). Its main processes involve identification, measurement and communication of human resources data to expedite effective organizational management. The practice of human resource accounting disclosure (HRAD) refers to the practice of recording, measuring, and presenting details of transactions related to employees in an organization including costs of recruitment, selection, performance, induction, training, development, welfare and payment of workers (Akintoye, Awoniyi, Jayeoba, \& Moses Ifayemi, 2016). 
The one of assumptions in financial reporting is accounting monetary unit assumption. However, the accounting monetary unit assumption of employees' values is challenging to report in financial statements as some measures are not tangible (Enyi \& Akindehinde, 2014; Widodo \& Widagdo, 2014).Consequently, much focus on recent studies has been on HRA model that could translate intangible assets such as employee commitment and training return of investment comprehensively.

There is a growing global interest towards the disclosures practices of HRA (Bullen \& Eyler, 2010) especially in developed countries such as United Kingdom (Flamholtz, E. G, Kannan-Narasimhan, R., and Bullen, 2004), Sweden (Ax, Marton, Ax, \& Marton, 2010) and Australia (Boedker, Guthrie, \& Cuganesan, 2004). There are also several attempts to examine disclosures practices of HRA in developing countries such as Sri Lanka (Abeysekera, 2008) and Bangladesh (Abdulla \& Mamun, 2009). Nonetheless, standardization of measurement remains a significant hurdle. Moreover, disclosure of human resource accounting is voluntary and not regulated (Luh \& Yusmarisa, 2016) which led not only to partial or no disclosure but also unstandardized reports eventhough on the stock market have specific requirements to public. To date, a study that compares HRAD practices among several countries is not available which indicates empirical chasm.

There are myriads of benefits related to HRA ranging from sound managerial planning and decision making, risk management, optimization of resources and improvement of employees' morale and satisfaction (Islam, 2013). In essence, sound HRA practices reflect organization's commitment towards better governance and accountability and could be a very good source of information for investors and stakeholders alike (Bratton \& Gold, 2003). In fact, Bratton and Gold (2003) are convinced that HRA information has more values for external parties compared to the organizations themselves. This is confirmed by the 2015 Global Investor Survey conducted by Ernst \& Young (EY) Indonesia that claimed investors have been paying more attention to non-financial aspects than finansial aspects of the corporates since two years ago. Unfortunately, minimal information about non-financial information from the corporates is available.

Responding to both the empirical and practical issues, this paper aims to compare HRADI practices of top 50 companies listed in the ASEAN Corporate Governance Scorecard using criteria proposed by (Abdulla \& Mamun, 2009) and D’Souza et al., (2005).

The ASEAN Corporate Governance Scorecard (ACGS) is one of the latest corporate governance assessment frameworks introduced by the ASEAN Capital Market Forum (ACMF) as a tool to rank the performance of public and open corporate governance in ASEAN. The ACGS is the standard for firms in ASEAN, especially in order to challenge the era of the ASEAN Economic Community (AEC). In 2011, The International Integrated Reporting Council (IIRC) introduced the ASEAN Corporate Governance Scorecard. IIRC, established in 2010, released an international integrated reporting framework in December 2013. The integrated reporting consists of important aspects including finance, manufacture, human resources (HR), intellectual, social relations, and nature. The development of the ACGS was initiated by the ASEAN Capital Market Forum (ACMF) in order to develop integrated capital markets and to promote ASEAN as an asset class. Therefore, it is expected that ASEAN corporates can increase their visibility among potential investors. Figure 1 shows percentage of firms participation in ACGS from each ASEAN country from year 2012 to 2015. It is evident that percentage of participation shows an increasing trend which signifies acceptance of ACGS as corporate governance assessment framework.

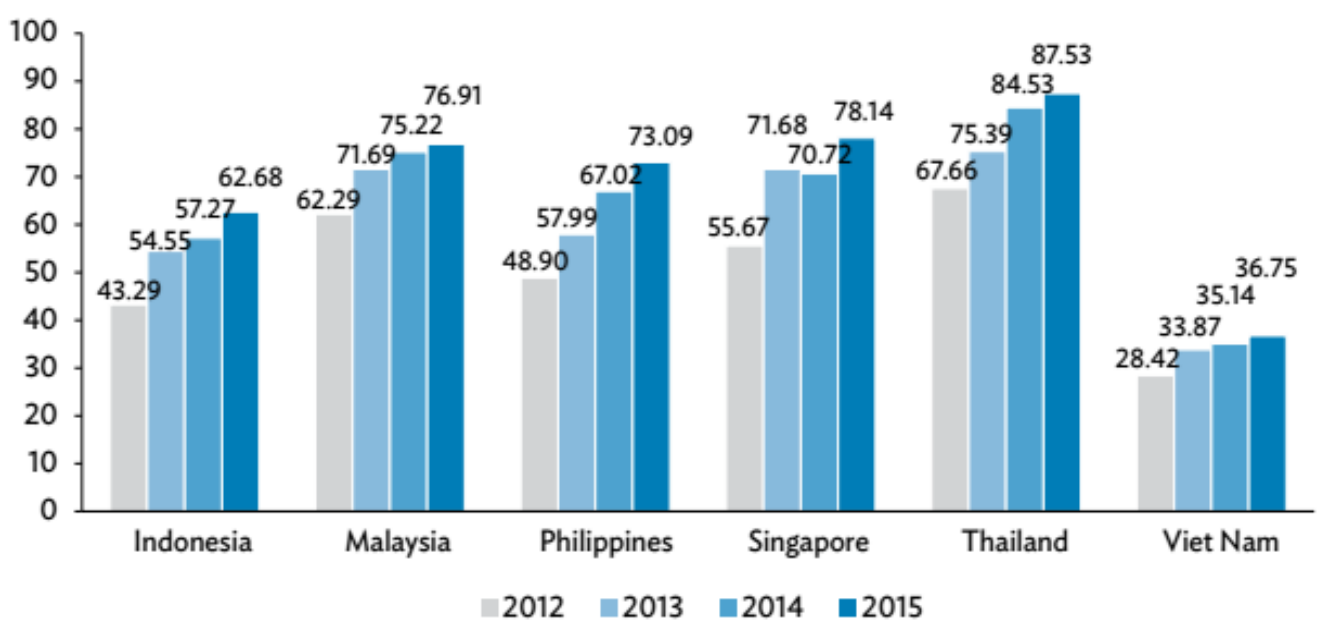

Source: ASEAN Corporate Governance Scorecard Country Reports and Assessments 2015

Figure 1. Average ACGS of each country 


\section{Literature Reviews}

This part discusses relevant theories and past studies related to HRAD practices.

\subsection{Relevant Theories}

There several theories commonly discussed with regards to HRAD practices which are Resource-Based Theory, Stakeholder Theory, and Signaling Theory. Resource-Based Theory is a generic theory concerning strategic management theory with the belief that organizations will achieve excellence if they have outstanding resources (Rohman, Si, Meiranto, Si, \& Diponegoro, 2010). This theory describes the relationship between resources and corporate strategy (S, Suranta, Negeri, \& Maret, 2018). Based on this theory, corporates must utilize all resources they possess. Organizational capabilities in terms of human resources will encourage corporates to disclose (Santioso, Alverianti, \& Daryatno, 2017).

According to Stakeholder Theory, activities that are considered significant by stakeholders must be reported back to the stakeholders by the management of the organization, since all stakeholders have the right to obtain information concerning corporate activities affecting them. As such, disclosure helps corporates to maintain relationships with stakeholders, so that management receives support for the survival of the corporate. On the other hand, stakeholders' trust in the corporate will increase if the needs for corporate information are fulfilled. This stakeholder theory strongly underlies the practice of human resources disclosure because of the relationship between corporate management and stakeholders.

Signaling theory, on the other hand, explains how a corporate should give a signal to users of financial statements in the form of information concerning management performance in realizing the owners' wants. Management will disclose information that has a capability to increase the level of credibility and the corporates' success even though the information is not legally required. The benefit of disclosing human resource accounting to principals is so that the provided information is to be utilized to understand the current condition of the human resources of the corporate, and to provide an understanding of the strategy on how the corporate uses its human resources. This information will reduce information asymmetry between the principal and the agent so that agency problems between the two parties can be minimized. In addition, the information also provides a positive signal to stakeholders. This positive signal from the corporate is likely to receive a positive response from the market leading to the increase in the stakeholder's assessment of the corporate.

\subsection{Empirical Studies}

Studies related to disclosure of human resource accounting are clustered into three major themes. The first cluster of studies has focusses on measurement and development issues with in the HRAD model (e.g. (Ghasemi, Shahin, \& Safari, 2018), while the second cluster has been focusing on the effects of HRAD on other variables such as performance (e.g. Ikpefan, Kazeem, \& Taiwo, 2015). Perhaps the most empirical studies have been focusing on third cluster which describes the extent of HRDA practices in respective countries. Table 1 summarizes recent 10 years studies on HRAD practices. The majority of newer studies are in the context of developing countries while studies in developed countries have shifted to HRAD model developments and its consequences.

Abdulla \& Mamun (2009) found that in Bangladesh, $25 \%$ of participating companies disclosed their human resource accounting while in later study, Ullah \& Karim, (2015) found that textile corporates in Bangladesh disclose almost $50 \%$ of the human resources in the annual report. About $58.30 \%$ of corporates disclose less than $50 \%$, $20.50 \%$ of corporates disclose $50 \%-60 \%$, and $20.60 \%$ of corporates disclose $60 \%-70 \%$ of HR information in annual reports. Exactly the HR information discloses 16 items which developed a model to measure human resource accounting disclosure based on relevant literature. The more detailed explanation of each item in this study referred to the study is conducted by Souza, Junior, Lagioia, and de Araujo (2016).

Enofe, Mgbame, Otuya, \& Ovie (2013) discovered that $82 \%$ of companies in Nigeria disclose less than $40 \%$ of their human resource accounting, while the remaining $18 \%$ disclose $40 \%-80 \%$ of their human resource accounting. In addition, this study shows that finance corporates disclose more information on human resource accounting than non-finance corporates.

Studies on HRAD practices in Malaysia revealed that Malaysian corporates are not ready for HRAD (Huang, Abidin, Mara, Lumpur, \& Jusoff, 2009; Kadir \& Mohan, 2018). Several issues are highlighted including difficulties to translate the intangible assets to monetary terms.

In Indonesia, Widodo and Widagdo found that banking corporates has high HRAD disclosure of $57 \%$ based on banking corporates listed on the Indonesian Stock Exchange in the period 2011-2014. In 2018, S. F. A. and Suranta (2018) replicated the research using secondary data from Indonesian Stock Exchange in 2013-2015 with similar findings. The degree of human resource accounting disclosure in Indonesia is high, compared to other developing countries including Bangladesh, Nigeria and India at $50.27 \%$. 
Table 1. Reporting of Human Resources Accounting Disclosure

\begin{tabular}{|c|c|c|c|c|}
\hline Authors & Title & Year & Method & Key Findings \\
\hline $\begin{array}{l}\text { Faiz Alafi S. } \\
\text { Sri Suranta }\end{array}$ & $\begin{array}{c}\text { Pengungkapan Akuntansi Sumber Daya Manusia Dan } \\
\text { Kinerja Keuangan Perusahaan }\end{array}$ & ( 2018) & $\begin{array}{c}\text { Quantitative using secondary } \\
\text { data }\end{array}$ & HRAD has a positive correlation on ROA, ATO, and MBV. \\
\hline $\begin{array}{l}\text { Abdul Kadir, M.R., } \\
\text { Mohan, T }\end{array}$ & $\begin{array}{l}\text { Human Resource Accounting Disclosure: A Qualitative } \\
\text { Study from Malaysian Perspective }\end{array}$ & ( 2018) & Qualitative- Interviews & $\begin{array}{l}\text { The study revealed significant result where the HRA is still distant } \\
\text { in current practice and not ready to be applied in Malaysian } \\
\text { context. }\end{array}$ \\
\hline Al Hanini E.A. & $\begin{array}{l}\text { Evaluation of measurement and disclosure methods of } \\
\text { human resources accounting in public shareholding } \\
\text { companies in Jordan }\end{array}$ & $(2018)$ & Questionnaire & $\begin{array}{l}\text { The HRAD among Jordanian public shareholding companies do } \\
\text { not apply its principles. High expenses and refusal of updating and } \\
\text { renewing the companies' human resources system are cited issues. }\end{array}$ \\
\hline $\begin{array}{l}\text { Venus C. Ibarra; Corazon } \\
\text { A. Cosico }\end{array}$ & $\begin{array}{l}\text { Awareness of Human Resource Accounting Practices } \\
\text { and Costing: Evidence from the Philippines }\end{array}$ & $(2016)$ & Questionnaires & $\begin{array}{l}48 \text { companies used the traditional or conventional accounting for } \\
\text { human resources, where costs incurred for human resources were } \\
\text { charged to expenses }\end{array}$ \\
\hline $\begin{array}{l}\text { Akintoye, Awoniyi, O., } \\
\text { Jayeoba, O. \& Moses } \\
\text { Ifayemi, O }\end{array}$ & $\begin{array}{c}\text { Improvement of Human Resource Accounting } \\
\text { Disclosures and Financial Statement Through IFRS: } \\
\text { Evidence from Nigeria }\end{array}$ & $(2016)$ & Quantitative & $\begin{array}{l}\text { There is no difference in the means of HRAD of financial } \\
\text { statements prepared under SAS compared with HRAD of financial } \\
\text { statement prepared under IFRS for the period pre and post adoption } \\
\text { of IFRS in Nigeria. }\end{array}$ \\
\hline Enyi, Patrick Enyi & Human Asset Accounting and Corporate Performance & ( 2014) & Questionnaires & $\begin{array}{l}\text { The human asset accounting significantly affects the } 18 \text { banks' } \\
\text { performance. Recommend its disclosure as an intangible asset in } \\
\text { the balance sheet. }\end{array}$ \\
\hline Authors & Title & Year & Method & Key Findings \\
\hline $\begin{array}{l}\text { Ikpefan O.A., Taiwo J.N., } \\
\text { Olokoyo W. }\end{array}$ & $\begin{array}{l}\text { Human capital accounting and performance of } \\
\text { microfinance banks (MFB) in Nigeria }\end{array}$ & ( 2015) & $\begin{array}{l}\text { Content Analysis via Annual } \\
\text { Reports. }\end{array}$ & $\begin{array}{l}\text { Results of this study shows that human resources accounting has a } \\
\text { significant effect on MFBs performance. }\end{array}$ \\
\hline $\begin{array}{l}\text { Oyewo B.M., Faboyede } \\
\text { O.S., Fakile A.S. }\end{array}$ & $\begin{array}{l}\text { Human resource management and accounting as } \\
\text { strategies for achieving Nigeria's global competitiveness } \\
\text { through vision } 2020 \text { actualization }\end{array}$ & $(2020)$ & $\begin{array}{l}\text { Quantitative using secondary } \\
\text { data }\end{array}$ & $\begin{array}{l}\text { There is no significant difference of HRDA practices between the } \\
\text { Financial and Manufacturing industries in Nigeria. There is a } \\
\text { strong positive relationship between HRMAD and company size. } \\
\text { The arbitrariness in reporting human resource management } \\
\text { activities is evident due to no legislation available. There is a lack } \\
\text { of uniformity in the presentation of information on human capital } \\
\text { in annual reports of companies in Nigeria. }\end{array}$ \\
\hline $\begin{array}{l}\text { Md Hafij Ullah, Md Helal } \\
\text { Uddin, Ruma Khanam }\end{array}$ & $\begin{array}{c}\text { The Relationship between Human Resource Disclosure } \\
\text { and Company Attributes: An Empirical Study on Textile } \\
\text { Companies in Bangladesh }\end{array}$ & $(2015)$ & Quantitative & $\begin{array}{c}50 \text { to } 60 \% \text { of companies disclose from less than } 50 \% \text { of HRAD } \\
\text { items. Size is related to HRAD. }\end{array}$ \\
\hline $\begin{array}{l}\text { Nova Maulud Widodo, Ari } \\
\text { Kuncara Widagdo }\end{array}$ & $\begin{array}{c}\text { Struktur Kepemilikan Terhadap Pengungkapan } \\
\text { Akuntansi Sumber Daya Manusia }\end{array}$ & ( 2014) & $\begin{array}{l}\text { Quantitative using secondary } \\
\text { data }\end{array}$ & $\begin{array}{l}\text { Foreign and family ownership have no significance influence on } \\
\text { the HRAD when size and age are controlled.. }\end{array}$ \\
\hline
\end{tabular}


Table 1 Continued

\begin{tabular}{|c|c|c|c|c|}
\hline Authors & Title & Year & Method & Key Findings \\
\hline $\begin{array}{l}\text { A.O. Enofe, C. Mgbam, } \\
\text { Sunday Otuya,Christopher } \\
\text { Ovie }\end{array}$ & $\begin{array}{c}\text { Human Resources Accounting Disclosures in Nigeria } \\
\text { Quoted } \\
\text { Firms }\end{array}$ & (2013) & Content Analysis & $\begin{array}{c}\text { Significant positive relationship between HRAD and financial } \\
\text { performance }\end{array}$ \\
\hline Syed Abdulla Al Mamun & $\begin{array}{l}\text { Human Resource Accounting (Hra) Disclosure Of } \\
\text { Bangladeshi Companies And Its Association With } \\
\text { Corporate Characteristics }\end{array}$ & $(2009)$ & $\begin{array}{l}\text { Quantitative using secondary } \\
\text { data }\end{array}$ & $\begin{array}{c}\text { Only } 25 \% \text { of companies disclose the total HRAD items. HRAD } \\
\text { was significantly related with company's size, category of the } \\
\text { company (financial or non-financial) and profitability. HDAD had } \\
\text { no influence on the age of companies. }\end{array}$ \\
\hline $\begin{array}{l}\text { Striukova, L., Unerman, J. } \\
\text { and Guthrie, J. }\end{array}$ & $\begin{array}{l}\text { Corporate reporting of intellectual capital: evidence } \\
\text { from UK companies }\end{array}$ & $(2008)$ & Content Analysis. & $\begin{array}{l}\text { Major differences between the elements of intellectual capital } \\
\text { reported in each sector studied. Different types of corporate reports } \\
\text { were used for communicating intellectual capital } \\
\text { information, and that the annual reports were not a good proxy for } \\
\text { the proportion of disclosures across all corporate reports. } \\
\text { The examination of the voluntary human capital reporting }\end{array}$ \\
\hline Huang et al., & External Reporting of Human Capital in Malaysia & $(2008)$ & $\begin{array}{l}\text { Content Analysis via Annual } \\
\text { Reports }\end{array}$ & $\begin{array}{l}\text { practices of top companies in Malaysia was found to be low Much } \\
\text { effort needs to be put } \\
\text { in to educate human resource managers on how to calculate human } \\
\text { resource costs, values, ROI and its outcomes }\end{array}$ \\
\hline Abeysekera, I. & $\begin{array}{c}\text { Motivations behind human capital disclosure in annual } \\
\text { reports }\end{array}$ & (2008) & Case Study via interviews & $\begin{array}{l}\text { It is suggested that the motivation behind disclosure relates to } \\
\text { gaining support from the capital market and appearing legitimate. } \\
\text { It is also used to reduce tension between firms and their capital, } \\
\text { social; and political constituents in the interest of further capital } \\
\text { accumulation. }\end{array}$ \\
\hline Authors & Title & Year & Method & Key Findings \\
\hline Vuontisjärvi T. & $\begin{array}{l}\text { Corporate social reporting in the European context and } \\
\text { human resource disclosures: An analysis of finnish } \\
\text { companies }\end{array}$ & (2006) & Annual Reports & $\begin{array}{c}\text { The results of the content analysis indicate that social reporting } \\
\text { practices are still at an early stage of development in Finland. The } \\
\text { most reported theme was 'training and staff development'. } \\
\text { However, disclosures lacked overall consistency and } \\
\text { comparability with each other and especially quantitative } \\
\text { indicators were disclosed by few. Further concern was lack of } \\
\text { information related to the theme equal opportunities and going } \\
\text { beyond a sheer disclosure of age or gender structure. The other } \\
\text { issues rarely disclosed were those related to employee work-life } \\
\text { balance and integration of disadvantaged groups in the labour } \\
\text { markets. }\end{array}$ \\
\hline
\end{tabular}




\section{Research Method}

\subsection{Population, Samples and Sampling Techniques}

This study used descriptive statistics to describe HRAD practices among top ranked companies based on ASEAN Corporate Governance Scorecard which include Indonesia, Malaysia, Vietnam, Philippines, Thailand and Singapore. Assessment of HRAD practices was done based on sixteen criteria based on previous studies. The population of this study was the 195 top ranked corporates in ASEAN Top Corporate Governance Scorecard (ACGS) 2014 - 2015 from Indonesia, Vietnam, Thailand, the Philippines, Malaysia and Singapore. The samples were selected using purposive sampling method. The purposive sampling criterion was that the corporates were listed on 50 Top Ranked in the ASEAN Corporate Governance Scorecard (ACGS) for the period 2014-2015. The next criterion is that the corporates published a complete and audited annual report for the period 2014-2015.

\subsection{Types and Data Sources}

The type of data used in this study was secondary data. The data used in this study were the annual financial statements of each sample corporate published on websites respective websites as shown in Table 2 .

Table 2. Research Data Sources

\begin{tabular}{cll}
\hline No & Countries & Websites \\
\hline 1 & Indonesia & $\underline{\text { www.idx.co.id }}$ \\
2 & Vietnam & $\underline{\text { www.hnx.vn }}$ \\
3 & Thailand & $\underline{\text { www.set.or.th }}$ \\
4 & The Philippines & $\underline{\text { www.pse.com }}$ \\
5 & Malaysia & www.bursamalaysia.com \\
6 & Singapore & $\underline{\text { www.sgx.com }}$ \\
\hline
\end{tabular}

\subsection{Data Analysis Technique}

The data analysis technique in this study was descriptive statistics. Descriptive statistics was a method of collecting and presenting data group to provide useful information. In the initial stage, the researchers collected all annual reports presented by each corporate. Furthermore, the researchers reviewed the Human resource accounting disclosure conducted by each sample corporate in the reports using the disclosure 16 indicators developed by Al Mamun (2009).

Al Mamun (2009) developed a model to measure human resource accounting disclosure based on relevant literature. For a better understanding of each disclosure item description, a more detailed explanation of each item in this study referred to the study conducted by Souza, Junior,
Lagioia, and de Araujo (2016). There are a total of 16 items as shown in Table 3. Items of human resource accounting disclosure were assessed using dichotomous procedures in which each corporate was given a ' 1 ' score if the corporate had made disclosures and ' 0 ' if otherwise. Then the total scores were averaged to find the net value of each corporate. The calculation used the following equation:

$$
H R A D=\frac{\text { Total score of individual company }}{\text { Maximum posible score obtained }} \times 100 \%
$$

\section{Results and Discussion}

This study described HRAD practices among top ranked companies based on ASEAN Corporate Governance Scorecard (ADGS). Assessment of HRAD practices was done based on sixteen criteria based on previous studies. The population of this study was the 195 top ranked corporates in ASEAN Top Corporate Governance Scorecard (ACGS) 2014 - 2015 from Indonesia, Vietnam, Thailand, the Philippines, Malaysia and Singapore. Total sample of 40 annual reports of Indonesian corporates, 19 Vietnamese corporates, 34 Thai corporates, 31 Philippine corporates, 38 Malaysian corporates and 33 Singaporean corporates were analyzed in this study. Table 4 shows the percentage of disclosure for each corporate in each country based on the HRAD criteria in Table 3.

The total value of human resources represented the cost of human resources by corporates in the form of wages. Table 4 shows that the lowest disclosure level regarding the total values of human resources was the disclosure made by corporates in the Philippines. However, the percentage is still high at $85.48 \%$ while other firms in other countries scored $100 \%$. As total value of human resource is part of annual financial reports, this result is expected.

In terms of number of employees, the highest disclosure level of the number of employees of human resources disclosure was made by corporate in Indonesia and Vietnam while Philippines and Singapore were the lowest. The probable reason might be attributed to many types of employment offered in this country such as part time, temporary workers or even freelancer. The HRAD usually refers to number of permanent employees and thus companies offering other types of employment might not report them.

Surprisingly, corporates in Singapore have the lowest disclosure level regarding human resource policies compared to other ASEAN countries. It is possible that their human resource policies are integrated with corporate policies and are not included in their annual reports. Similarly, Singapore remains low at $46.9 \%$ in disclosing their training and development activities. 
Table 3. Index of Human Resource Accounting Disclosure

\begin{tabular}{|c|c|c|}
\hline No & Disclosure Items & Definitions \\
\hline 1 & Separate HRA statement & $\begin{array}{l}\text { The expression "Separate HRA Statement" refers to corporates that publish a specific report on } \\
\text { how the organization deals with and invests in Human Resources. Therefore, the existence of } \\
\text { these "independent" declarations (i.e. separate from the Standardized Financial Statements and } \\
\text { the Annual Management Report) which refer exclusively to human resources was also verified. }\end{array}$ \\
\hline 2 & $\begin{array}{l}\text { Total Value of Human } \\
\text { Resource }\end{array}$ & Refers to spending on Human Resources (mostly salaries). \\
\hline 3 & Number of employees & Refers to the number of people working in the corporate as effective employees. \\
\hline 4 & Human resource policy & $\begin{array}{l}\text { Refers to the coordinated and strategic action focused on the development of people in the } \\
\text { organization. }\end{array}$ \\
\hline 5 & Training and development & $\begin{array}{l}\text { Is related to what the corporate spent to improve its employees' performance. In one word: } \\
\text { training. }\end{array}$ \\
\hline 6 & $\begin{array}{l}\text { Management succession } \\
\text { plan }\end{array}$ & $\begin{array}{l}\text { Refers to salary and career planning in the organizational chart and hierarchical model the } \\
\text { corporate proposes. }\end{array}$ \\
\hline 7 & Employment report & Reports on employee movements (admission and resignation flow) in the organization. \\
\hline 8 & Employees`value addition & Refers to how much of the value added the corporate produced was distributed among employees. \\
\hline 9 & $\begin{array}{l}\text { Human resource } \\
\text { development fund }\end{array}$ & $\begin{array}{l}\text { Refers to entities that have their own budget or a clearly defined fund, as the term itself says, for } \\
\text { staff policies. }\end{array}$ \\
\hline 10 & Employees/workers fund & $\begin{array}{l}\text { Are special conditions to respond to employees' financial demand, usually defined through down } \\
\text { payments and/or loan policies. }\end{array}$ \\
\hline 11 & Employee categories & $\begin{array}{l}\text { Possible differences in employees' internal classification. This classification can refer to the } \\
\text { department where these employees work, the type of professional relationship they maintain with } \\
\text { the corporate or the socioeconomic profile of the staff. }\end{array}$ \\
\hline 12 & Managerial remuneration & $\begin{array}{l}\text { Represents the compensation (not necessarily individualized per executive) paid to the top level } \\
\text { of the investigated entities (normally in the form of bonus or stock options). }\end{array}$ \\
\hline 13 & Retirement benefits & $\begin{array}{l}\text { Refers to possible benefits (such as the creation of clubs, awards) granted to retired employees as } \\
\text { recognition of merit and contribution they gave while active, as well as actions to enhance these } \\
\text { persons' wellbeing. }\end{array}$ \\
\hline 14 & Performance Recognition & $\begin{array}{l}\text { This component is linked to additional compensation plans (vouchers, awards etc.), outlined to } \\
\text { compensate best performances. Includes participation in profits and income. }\end{array}$ \\
\hline 15 & Superannuation fund & Refers to the private health insurance for employees, fully or partially paid for by the corporate. \\
\hline 16 & Other employees’ benefits & $\begin{array}{l}\text { Includes all investments and actions focused on Human Resources, mentioned in the text of the } \\
\text { reports, which somehow were not grouped in the other items. Thus, the goal is to prevent } \\
\text { important information from being ignored solely for not being part of the theoretical model } \\
\text { underlying this research. }\end{array}$ \\
\hline
\end{tabular}

Source: (Abdulla \& Mamun, 2009); (Souza, Junior, Lagioia, \& de Araujo, 2016)

Employment reports contained reports on employee activities including the employment and resignation of employees in the organization. Almost all corporates from the ASEAN countries have low percentage of disclosure ranging from $36.25 \%$ to $12.12 \%$. As HRAD is not made mandatory and the compilations of tremendous amount of data are required to produce the employment reports, the corporates might as well be focusing on other aspects.

Malaysia has the lowest disclosure percentage with regards to management succession plans compared to other ASEAN countries. This result is aligned with the Malaysian Family Business Survey 2016 that show succession planning is a key challenge as $62 \%$ of businesses lack of a proper strategic plan to manage succession process (PWC, 2016).

Employees' additional value referred to how much additional value the corporate generated to be distributed among employees. Corporates in the Philippines have yet widely disclosed the employees' addition value in their annual reports with only $25.81 \%$ have done so.

Corporates in Thailand and Malaysia have the lowest disclosure level regarding human resource development funds, at the percentage of $15 \%$ while corporates in Vietnam have the highest percentage (yet moderate at 50\%) of disclosures regarding employee or workers funds in their annual reports.

Employee category referred to the internal classification of employees. This classification can also refer to the department where employees work or refer to the professional relationships they maintain with the corporate or the socioeconomic staff. This result is consistent with the trend observed for reporting of number of employees where Singapore and Philippines remain low in comparison with other countries.

Almost all corporate disclosure their managerial remuneration in their annual reports. As managerial remuneration has significant portion of human resource cost, its disclosure is important for tax-deduction purposes. Contrarily, retirement benefits in general have low to moderate disclosure percentage across ASEAN countries with Thailand have the highest disclosure level at 51.47\%.

Corporates in Philippines and Singapore have the lowest disclosure of performance recognition and other employees' benefits in their annual reports as shown in Table 4. Other employee benefits include all investments and HR-focused 
actions stated in the report text that are not categorized in other items. Finally, superannuation funds referred to personal health insurance for employees, paid fully or partly by the corporate. Corporates in Singapore had the lowest disclosure level regarding superannuation funds in their annual reports compared to the other ASEAN countries.

In terms of accumulated scores, Indonesia scored the highest in terms of HRAD practices followed by Thailand and Vietnam.

Table 4. Percentage of HRAD Practices

\begin{tabular}{|c|c|c|c|c|c|c|}
\hline & Indonesia & Vietnam & Thailand & Philippines & Malaysia & Singapore \\
\hline Number of Corporates & 40 & 19 & 34 & 31 & 38 & 33 \\
\hline Separate HRA statement & $0.00 \%$ & $0.00 \%$ & $0.00 \%$ & $32.30 \%$ & $52.60 \%$ & $0.00 \%$ \\
\hline Total value of human resource & $100 \%$ & $100 \%$ & $100 \%$ & $85.48 \%$ & $100 \%$ & $98.48 \%$ \\
\hline Number of employees & $100.00 \%$ & $100.00 \%$ & $80.88 \%$ & $43.55 \%$ & $84.21 \%$ & $43.94 \%$ \\
\hline Human resource policy & $100.00 \%$ & $92.11 \%$ & $95.59 \%$ & $66.13 \%$ & $96.05 \%$ & $40.91 \%$ \\
\hline Training and development & $100.00 \%$ & $89.47 \%$ & $92.65 \%$ & $72.58 \%$ & $96.05 \%$ & $46.97 \%$ \\
\hline Management succession plan & $80.00 \%$ & $42.11 \%$ & $48.53 \%$ & $27.42 \%$ & $11.84 \%$ & $68.18 \%$ \\
\hline Employment report & $36.25 \%$ & $26.32 \%$ & $32.35 \%$ & $17.74 \%$ & $15.79 \%$ & $12.12 \%$ \\
\hline Employees`value addition & $36.25 \%$ & $52.63 \%$ & $76.47 \%$ & $25.81 \%$ & $92.11 \%$ & $66.67 \%$ \\
\hline Continue & Indonesia & Vietnam & Thailand & Philippines & Malaysia & Singapore \\
\hline Number of Corporates & 40 & 19 & 34 & 31 & 38 & 33 \\
\hline Human resource development fund & $76.25 \%$ & $50.00 \%$ & $16.18 \%$ & $17.74 \%$ & $15.79 \%$ & $24.24 \%$ \\
\hline Employees or workers fund & $41.25 \%$ & $52.63 \%$ & $35.29 \%$ & $12.90 \%$ & $34.21 \%$ & $3.03 \%$ \\
\hline Employee categories & $98.75 \%$ & $68.42 \%$ & $66.18 \%$ & $35.48 \%$ & $52.63 \%$ & $28.79 \%$ \\
\hline Managerial remuneration & $95.00 \%$ & $92.11 \%$ & $92.65 \%$ & $85.48 \%$ & $94.74 \%$ & $100.00 \%$ \\
\hline Retirement benefits & $43.75 \%$ & $42.11 \%$ & $51.47 \%$ & $14.52 \%$ & $13.16 \%$ & $18.18 \%$ \\
\hline Performance Recognition & $76.25 \%$ & $71.05 \%$ & $85.29 \%$ & $33.87 \%$ & $86.84 \%$ & $42.42 \%$ \\
\hline Superannuation fund & $91.25 \%$ & $78.95 \%$ & $88.24 \%$ & $64.52 \%$ & $61.84 \%$ & $59.09 \%$ \\
\hline Other employees’ benefits & $73.75 \%$ & $68.42 \%$ & $91.18 \%$ & $37.10 \%$ & $92.11 \%$ & $31.82 \%$ \\
\hline $\begin{array}{l}\text { Human resource accounting } \\
\text { disclosures }\end{array}$ & $71.80 \%$ & $64.15 \%$ & $65.81 \%$ & $45.67 \%$ & $59.54 \%$ & $42.80 \%$ \\
\hline
\end{tabular}

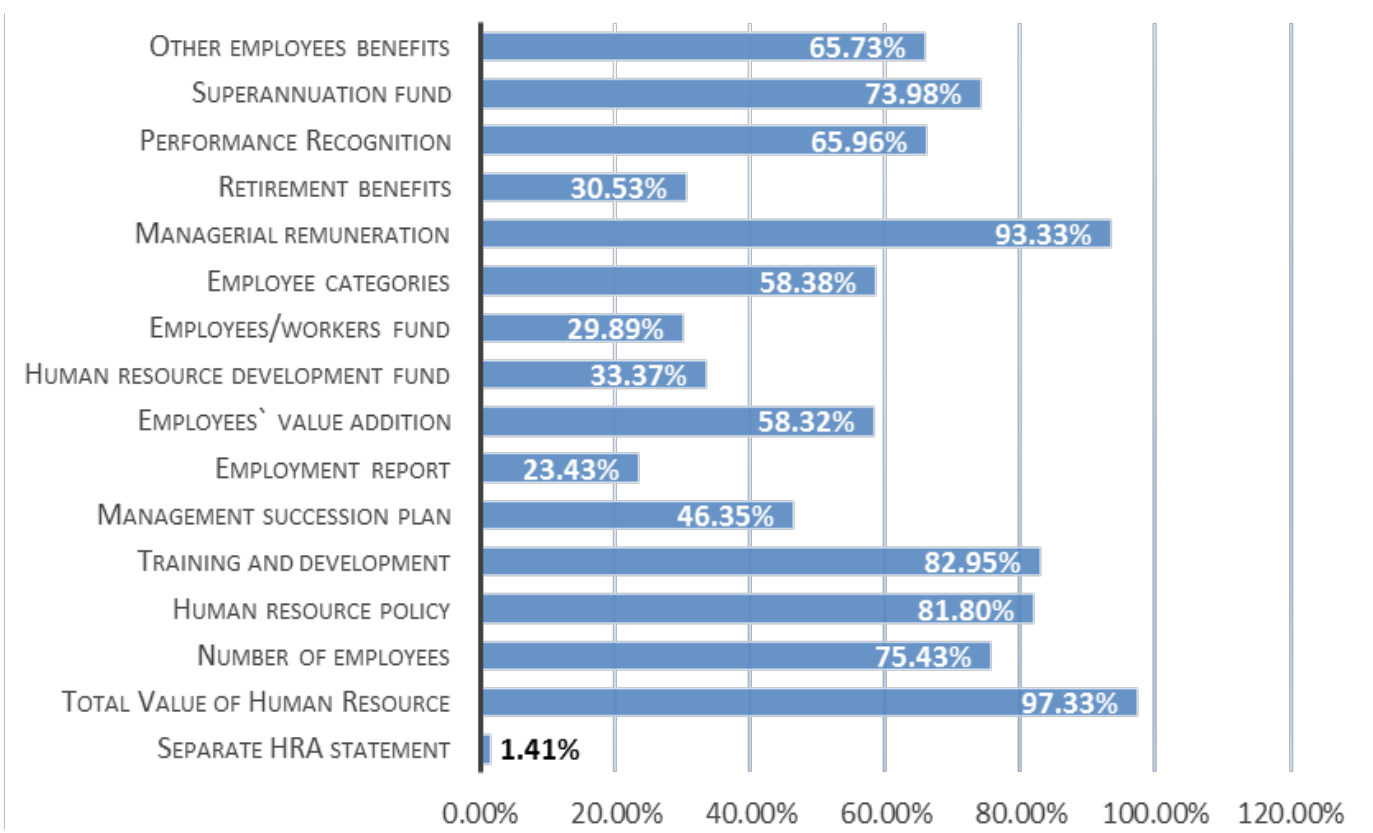

Figure 2. HRA Disclosures of All Corporates 
Figure 2 shows all the 16 items assessed for HRAD. The lowest percentage of practice is the separate reporting for HRAD statement (1.41\%), followed by employment report (23.43\%), employees fund (29.89\%) and retirement benefits (30.53\%). It is evident that the acceptance of the most companies is very low, and they used the traditional or conventional accounting for human resources, so costs incurred for human resources were charged to expenses (Ibarra et al., 2016).

The highest level of HRAD by corporates is regarding managerial remuneration (46.35\%), training and development (82.95\%), HR policy (81.80\%) and total HR value (97.33\%). Almost all corporate disclosure their managerial remuneration in their annual reports. As managerial remuneration has significant portion of human resource cost, its disclosure is important for tax-deduction purposes. It is possible that their human resource policies are integrated with corporate policies and are not included in their annual reports. As total value of human resource is part of annual financial reports, this result is expected.

\section{Conclusion and Recommendations}

Our descriptive findings substantiate previous studies in terms of low to moderate level of HRAD practices around the globe. Much work needs to be done in forms of regulating the HRAD, standardization of HRAD assessment and promoting HRAD as sound corporate governance framework. There should be standards developed to identify and measure human resources. This is likely to improve the assessment of human capital, to ensure higher utility levels for stakeholders and consistency in disclosure, and to provide a more reliable value comparison of human capital. Moreover, an index-based assessment could facilitate the HRAD assessment to yield accurate and comparable results across time and corporates. Future research should be focusing on the impact of HRAD on effective governance, firm performance, employer's brand and labor market participation.

\section{REFERENCES}

[1] Abdulla, S., \& Mamun, A. (2009). Human Resource Accounting ( HRA ) Disclosure Of Bangladeshi Companies And Its Association With Corporate Characteristics, V(1), 35-43.

[2] Abeysekera, I. (2008). Motivations behind human capital disclosure in annual reports. Accounting Forum, 32(1), 1629.

[3] Akintoye, I. R., Awoniyi, O., Jayeoba, O., \& Moses Ifayemi, O. (2016). Improvement Of Human Resource Accounting Disclosure Practice In Financial Statements Through Ifrs: Evidence From Nigerian. International Journal Business and Commerce, 5(7).
[4] Ax, C., Marton, J., Ax, C., \& Marton, J. (2010). Human capital disclosures and management practices. http://doi.org/10.1108/14691930810892027

[5] Beattie, V., Smith, S. J., \& Beattie, V. (2010). Human capital, value creation and disclosure.http://doi.org/10.1108/140133 81011105957

[6] Boedker, C., Guthrie, J., \& Cuganesan, S. (2004). The Strategic Significance of Human Capital Information in Annual Reporting. Journal of Human Resource Costing \& Accounting, 8(2), 7-22.

[7] Boudreau, J. W., \& Ramstad, P. M. (2005). , Talent Segmentation, And Sustainability: A New Hr Decision Science Paradigm For A New Strategy Definition, 44(2), 129-136. http://doi.org/10.1002/hrm.20054

[8] Bratton, J., \& Gold, J. (2003). Human Resource Management: Theory and Practice. Palgrave Macmillan.

[9] Bullen, M. L., \& Eyler, K. (2010). Human resource accounting and international developments : implications for measurement of human capital. Journal of Internal Business and Cultural Studies, 1-16.

[10] Chand, M., \& Katou, A. A. (2007). The impact of HRM practices on organisational performance in the Indian hotel industry. http://doi.org/10.1108/01425450710826096

[11] D’Souza, R. M., Strazdins, L., Clements, M. S., Broom, D. H., Parslow, R., \& Rodgers, B. (2005). The health effects of jobs: status, working conditions, or both? Australian and New Zealand Journal of Public Health, 29(3), 222-228. http://doi.org/10.1111/j.1467-842X.2005.tb00759.x

[12] Eman Ahmad, A. H. (2018). Evaluation of Measurement and Disclosure Methods of Human Resources Accounting in Public Shareholding Companies in Jordan. Academy of Accounting and Financial Studies Journal, 22(4).

[13] Enofe, A. O., Mgbame, C., Otuya, S., \& Ovie, C. (2013). Human Resources Accounting Disclosures in Nigeria Quoted Firms, 4(13), 7-13.

[14] Enyi, E. P., \& Akindehinde, A. O. (2014). Human Resource Accounting and Decision Making in Post-Industrial Economy. American International Journal of Contemporary Research, 4(2), 110-118.

[15] Flamholtz, E. G, Kannan-Narasimhan, R., and Bullen, M. L. (2004). Human Resource Accounting today: Contributions, controversies and conclusions. Journal of Human Resource Costing and Accounting, 8(2), 23-37.

[16] Flamholtz, E. G., \& Bullen, M. L. (2002). Human resource accounting : a historical perspective and future implications, (December). http://doi.org/10.1108/00251740210452818

[17] Ghasemi, S., Shahin, A., \& Safari, A. (2018). Proposing an improved economic value model for human resource valuation. http://doi.org/10.1108/IJPPM-02-2018-0054

[18] Huang, C., Abidin, Z. Z., Mara, K. U. P., Lumpur, K., \& Jusoff, K. (2009). External Reporting of Human Capital in Malaysia External Reporting of Human Capital in Malaysia. Asian Social Sciences, 4(8), 3-11. http://doi.org/10.5539/ass .$v 4 n 8 p 3$

[19] Ibarra, V. C., Cosico, C. A., \& City, C. (2016). Awareness of Human Resource Accounting Practices and Costing: 
Evidence From Vietnam 10(4), 27-42.

[20] Ikpefan, O. A., Kazeem, B. L., \& Taiwo, J. N. (2015). Human Capital Accounting and Performance of Microfinance Banks ( MFB ) in Nigeria. Research Journal of Finance and Accounting, 6(1), 65-76.

[21] Islam, A. (2013). Human Resource Accounting : Recognition and. Measurement. Global Journal of Management and Business Research Accounting and Auditing, 13(3), 1-10.

[22] Izvercianu, M., Radu, A., Miclea, S., \& Ivascu, L. (2012). Competitiveness as a Result of Human Resources Marketing, 62-66. http://doi.org/10.7763/IPEDR.

[23] Kadir, M. R. A., \& Mohan, T. (2018). Human Resource Accounting Disclosure: A Qualitative Study from Malaysia Perspective. In Social \& Behavioural Sciences IEBMC 2017 8 th International Economics and Business Management Conference.

[24] Kong, E., \& Thomson, S. B. (2009). An intellectual capital perspective of human resource strategies and practices. Knowledge Management Research \& Practice, 7(4), 356364. http://doi.org/10.1057/kmrp.2009.27

[25] Luh, N. I., \& Yusmarisa, R. (2016). Pengaruh Karakteristik Perusahaan Bidang Pariwisata Pada Pengungkapan Akuntansi. Jurnal Bisnis Hospitaliti, 5(1), 48-55.

[26] Michael, O. B., Samuel, F. O., \& Adeniran, F. (2020). Human Resource Management and Accounting as Strategies for Achieving Global Competitiveness and Vision 2020 in Nigeria, 2014(2014). http://doi.org/10.5171/2014.826622

[27] PWC. (2016). Family Business Survey 2016.

[28] Rohman, H. A., Si, M., Meiranto, W., Si, M.,(2010). Implikasi Intellectual Capital Terhadap Financial Performance, Growth Dan Market Value; Studi Empiris
Dengan Pendekatan Simplistic Specification. In Simposium Nasional Akuntansi XIII. Diponegoro University (pp. 1-29).

[29] S, F. A., Suranta, S.,. (2018). Pengungkapan Akuntansi Sumber Daya Manusia. Universitas Sebelas Maret 6(1), 6274.

[30] Santioso, L., Alverianti, A., \& Daryatno, A. B. (2017). Akuntansi Sumber Daya Manusia. Jurnal Akuntansi, 17(2), 111-124.

[31] Souza, G. H. C., Junior, L. A. F., Lagioia, U. C. T., \& de Araujo, J. G. N. (2016). Financial Performance and Information Disclosure on Human Resources: an Analysis of Companies in The IBrX - 100 Umbelina Cravo Teixeira Lagioia. Journal of Education and Research in Accounting, 22(5), 88-102. http://doi.org/10.17524/repec.v10i1.1320

[32] Striukova, L., Unerman, J., \& Guthrie, J. (2008). Corporate reporting of intellectual capital: Evidence from UK companies. The British Accounting Review, 40(4), 297-313. http://doi.org/10.1016/j.bar.2008.06.001

[33] Ullah, H. (2015). Relationship between Human Resource Disclosure and Company Attributes : An Empirical Study on Textile Companies in Bangladesh, (July). http://doi.org/10.5296/ijafr.v4i2.6708

[34] Ullah, H., \& Karim, T. (2015). Human Resource Disclosure in Annual Report of the Listed Banking Companies in Bangladesh, 2(1), 7-19.

[35] Vuontisja, T. (2006). Corporate Social Reporting in the European Context and Human Resource Disclosures: An Analysis of Finnish Companies, 331-332. http://doi.org/10. 1007/s10551-006-9094-5

[36] Widodo, N. M., \& Widagdo, A. K. (2014). Struktur kepemilikan terhadap pengungkapan akuntansi sumber daya manusia. In Simposium Nasional Akuntansi XIII. 